mental restrictions on imports to a minimum, and of utilizing the European Plant Protection Organization as a reporting centre in the event of suspected trouble arising.

The quarantine working party was concerned with four specific plant troubles-- Colorado beetle, San José scale, potato root eelworm and potato wart disease. A short account is given of each pest or disease, and the manner by which it spreads. Its control is then discussed in the light of present scientific knowledge so that any legislation imposed may be adequate but not unnecessarily restrictive. For example, distinction is made between the quarantine requirements needed during the active and the hibernating periods of the Colorado beetle. Where fumigation has to be enforced, as in the case of nursery stocks likely to be infected with San José scale, it is suggested that some body such as the European Plant Protection Organization might act as adjudicator on the adequacy of the fumigation arrangements of the exporting country, thereby saving the importer a further fumigation. Other practical recommendations are the discouragement of growing potatoes in nurseries and a plea for the adoption by all countries of a uniform system of soil sampling for eelworm detection. Details of a suitable technique for the latter are given in an appendix. The reports are published in both French and English.

\section{Organization of Nationalized Industries}

NATIONALIzED industry forms the theme of a series of research papers published by the Acton Society Trust, and in a recent addition to this series, entitled "Patterns of Organisation" (Nationalized Industry Series No. 9; pp. 32 ; Claygate: Acton Society Trust, $1951 ; 2 s$.$) , is found a description of$ the structure of the various nationalized boards together with a critical appraisal of the assumptions underlying their structure. The idea that large organizations are more efficient than small took firm root in the thinking of the inter-war years. Technicians and engineers were absorbed by the idea of being able to plan for bigger units; the trade-union movement was dominated by the idea of rolying upon national agreements to prevent inequitable treatment in any single area; and when the Second World War came, administrators learned successfully how to operate nation-wide controls. The present patterns of organization have been determined by the coincidence in time of these trends; and the Acton Society Trust pamphlet points out that it has been too readily assumed that the limiting factor is the capacity of management to manage, to the neglect of much evidence that the limiting factor resides in the capacity and needs of the workman. The human factors-desire for status, resistance to change, fear of the future-impede the introduction of changes which the new regime was intended to bring about. Basic units in each industry should be small enough to preserve loyalties and personal contacts between managements and employees and between the industry and the public. It is also argued that the co-ordination of these units can be achieved by some much looser system of organization than that at present operating.

\section{Shirley Institute : Report for 1950}

THE "Shirley Institute Year Book, 1951" (pp. 125; Manchester: British Cotton Industry Research Association, 1951) includes, besides the annual report for 1950, concise accounts of its present organization and services to members with plans of the proposed extensions and the existing offices, laboratories and workrooms, and a chronology of the Institute's historical background and growth. The annual report includes an account of the ceremony on June 14, 1950 , of the laying of a foundation stone for the new building scheme, with reports of the speeches made then and at the annual general meeting of the Association on November 9, 1950. Tributes are paid in the report to the services of Dr. J. C. Withers, who retired at the end of September 1950 after thirty years of service as head of the Information Bureau, chief librarian and editor of the "Summary of Current Literature", and to L. H. C. Tippett, head of the Mechanical Processing Division, who was awarded the Warner Medal of the Textile Institute on June 8. The major change in internal administration during the year was the appointment of J. $\mathrm{H}$. Black as head of a new Information Department to co-ordinate all the information services of the Institute, including the library, abstracting, technical inquiries and publications, and the illustration office. Among research results stress is laid on the successful industrial application of the Shirley accelerated drying device and the introduction of the Shirley automatic size box, a revolutionary method of regulating the percentage of size added to the warp before weaving. The Shirley electrostatic eliminator, designed for the rapid removal of static electricity in high-speed processes, seems likely to be of value in other industries. Besides a list of members on January 1, 1951, appendixes to the report give details of the Council, committees of Council, publications of the Institute in 1950, and periodicals taken by and books added to the Library.

\section{Italian Society of Geophysics and Meteorology}

ThE Italian Meteorological Society, founded in 1881, unfortunately had to discontinue its activities during the Second World War. Prof. M. Bossolasco, Geophysical Institute, University of Genoa, who has been very active of recent years in the organization of international geophysical symposia in Italy, now writes, as secretary, to announce the foundation during May of the Italian Society of Geophysics and Meteorology. The Society's interests are planned to cover a very wide scope: they will include meteorology with climatology and bioclimatology, terrestrial magnetism, atmospheric and telluric electricity and radioactivity, seismology, volcanology, oceanography, hydrology, geodesy and geophysical prospecting and their applications. It is planned to begin publication of a Bulletin in the autumn. Membership, which is stated to be already some 120 , is open to foreigners as well as Italians, and applications are invited; the annual subscription, which covers supply of the Society's publications, is only 500 lire. British geophysicists and meteorologists will wish the new Society every success.

\section{Plastics Industry Education Fund}

THE trustees of the Plastics Industry Education Fund, the chairman of which is Mr. P. C. Allen, have recently announced that the total sum they have made available or authorized for expenditure during $\mathbf{1 9 5 2}$ is $£ 4,700$. Some of the details of this money are as follows. $£ 1,000$ is to be made available during the year for the award of ten training grants for students and $£ 100$ for travelling and educational expenses for apprentices attending recognized technical colleges. 